\title{
Valuing the impact of the teacher librarian from an evidence base
}

Ann Gillespie

PO Box 85, Petrie, 4502, Australia.

Email: anngillespie@uqconnect.net

\begin{abstract}
Evidence-based practice as it applies to the Library and Information (LIS) sector and in particular teacher librarians is the focus of this research investigation. The context for this research is Australian school libraries and teacher librarians. This is a research in progress and the report here will include some very early findings and lessons learned from the initial pilot study.
\end{abstract}

The contributions of this research will be in developing a framework for the library and information sector with a particular application for teacher librarians.

Providing meaningful evidence of work practices that demonstrate contributions to the schools goals and mission statements in conjunction with contributions to student academic, social and cultural achievements are crucial for the future of the teacher librarian.

Keywords: evidence-based practice, teacher librarians, expanded critical incident technique (ECIA)

\section{Introduction}

This is a research in progress and this preliminary report aims to add to the conversation about how teacher librarians perceive and use evidence-based practice. At a time when Australian schools are undergoing an 'education revolution', teacher librarians can play a vital role in supporting student learning and curriculum development. With dual qualifications as information professionals and educators, teacher librarians may contribute to the planning and implementation of innovative learning spaces and approaches. However, research and practitioner anecdotes indicate that this potential of teacher librarians is often under-valued within school communities and employing authorities. Therefore, the research described in this paper aims to enhance the impact of teacher librarians and their work by developing a framework for evidence-based practice.

It is proposed as this study reaches its conclusion, that evidence-based practice has the potential to demonstrate the value of the teacher librarian. Providing meaningful evidence of work practices that demonstrate contributions to the schools goals and mission statements in conjunction with contributions to student social, cultural and academic, achievements are crucial for the future of the teacher librarian. Using trustworthy evidence, it is possible that the teacher librarian is able to demonstrate the contributions they make to student learning, as well as inform decision making for the future development of the library and its activities.

Evidence-based practice is becoming well established in medicine, health services and education, as well as the wider librarianship field. However, a review of the literature reveals that there is not an empirically derived framework of evidence-based practice that applies to the library and information sector or specifically to the teacher librarian. This study will address the current need for a definition and framework specific to the school library context and teacher librarian role. The particular focus for this research is Australian school libraries and teacher librarians.

As this paper indicates, developing a framework for evidence-based practice for teacher librarians is problematic due to two main factors. Firstly, the evolving nature of evidence-based practice and the various understandings of what evidence-based practice is and its place in research and practice; and secondly, the complexity and dual nature of the teacher librarian's role.

(C) 2010 IASL, SLAQ and therein by the authors. Diversity Challenge Resilience: School Libraries in Action Proceedings of the $12^{\text {th }}$ Biennial School Library Association of Queensland, the $39^{\text {th }}$ International Association of School Librarianship Annual Conference incorporating the $14^{\text {th }}$ International Forum on Research in School Librarianship, Brisbane QLD Australia, 27 September - 1 October 2010. 
To develop the framework it is necessary to understand how teacher librarians perceive evidence-based practice. Specifically, this research seeks to answer the questions:

What constitutes evidence-based practice in teacher librarianship?

and

Within the context of teacher librarianship and evidence-based practice - What is evidence?

The methodology applied to this research is the Expanded Critical Incident Approach (ECIA) adapted by Hughes (2007) from Flanagan's (1954) Critical Incident Technique (CIT). ECIA is a qualitative and interpretive research approach which seeks to gain insight through actions, thoughts and feelings (Hughes, 2007, p.51).

The contributions of this research will be in developing a framework of evidence-based practice for the library and information sector with a particular application for teacher librarians. This framework will be developed from and supported with empirical research, with a purpose to provide a structure for teacher librarians to underpin their practice and demonstrate the value their contributions to the social, cultural and academic achievements of students from an evidence base.

\section{Literature Review}

This literature review introduces and critically considers the evolution and key elements of evidence-based practice in medicine, the health sector, library and information services, education and teacher librarianship. It includes a brief history and a description of the teacher librarians' role. The gaps in the research and the need for a framework which supports teacher librarians and evidence-based practice are explored.

\section{Evidence-based practice and its origins from the medical sector}

The concept of evidence-based practice has diffused from the medical sector to support professional activity in various fields including social work, probation, education and human resource management and library and information services. Perhaps the most widely cited definition of evidence-based medicine comes from Sackett et al:

Evidence-based medicine is the conscientious, explicit, and judicious use of current best evidence in making decisions about the care of individual patients. The practice of evidencebased medicine means integrating individual clinical expertise with the best available external clinical evidence from systematic research (1996, p.71).

Models for implementing evidence-based medicine have been evolutionary across all sectors where it has been implemented. The medical models are linear with a focus on scientific evidence. The model from Rosenberg and Donald (1995, p.1122) is typical of the approach adopted by the medical sector:

define the clinical question

retrieve the pertinent literature/information

evaluate the literature

categorise quality of evidence-based practice

develop conclusion and recommendation

Evidence-based medicine places evidence in a hierarchy, with scientific, random controlled trials held in the highest regard. Evidence-based medicine's 'external clinical evidence from systematic research' relies on evidence developed from randomised controlled trials. Critics of evidence-based medicine question the acceptance that randomised controlled trials are without bias (Grahame-Smith, 1995; Hunsucker, 2007; Little, 2003). This approach disregards, and devalues evidence which has derived from human and social interactions and observations. Perhaps this does not tell the whole story.

(C) 2010 IASL, SLAQ and therein by the authors. Diversity Challenge Resilience: School Libraries in Action Proceedings of the $12^{\text {th }}$ Biennial School Library Association of Queensland, the $39^{\text {th }}$ International Association of School Librarianship Annual Conference incorporating the $14^{\text {th }}$ International Forum on Research in School Librarianship, Brisbane QLD Australia, 27 September - 1 October 2010. 
Evidence-based practice in the broader medical and health sector seems to take two approaches. These are the external, scientific approach favoured by the medical practitioners and the internal, intuitive approach favoured in the nursing sector; however the lines are not clearly drawn for each sector; there is evidence of overlap as the concept of evidence-based practice evolves.

The nursing and the health sectors have also taken an evolutionary path in evidence-based practice. The models when first adopted also took a linear approach (Lomas, 1993), but it was not until the research of Kitson, Harvey \& McCormack (1998) that a framework with a basis in research specific to the nursing sector was developed. The main point of difference in the Kitson, Harvey \& McCormack framework is that evidence-based practice took into consideration the elements of facilitation and context (situation and workplace) with a purpose to transform or change practice. Recognising that facilitation and context played a role in evidence-based practice moved evidence-based practice from the positivist, quantitative domain to the interpretive, qualitative domain. Using this approach, evidence-based practice could fill the gap between research and practice.

Taking a broader, perhaps more socially oriented view of evidence, Rycroft-Malone et al (2004) argue that knowledge can be generated from four types of evidence:

\author{
Research \\ Clinical experience \\ Patients, clients and carers \\ Local context and environment.
}

The nursing and healthcare professions draw on a diversity of information sources to inform their decision making. The sources of evidence 'do not conform to traditional notions of rigour and robust evidence; rather they conform to rigour within critical social science' (Rycroft-Malone et al, 2004, p.88).

One clear point of distinction between the medical sector and the nursing and health sector is that the medical sector places evidence in a hierarchy, with random controlled trials residing at the top as a premier source of knowledge. A suggestion for the nursing sector from Scott-Findlay \& Pollock (2004) is that the nursing profession separate evidence into research and findings/knowledge. Personal experience and experiential knowledge 'should be recognised for what they are and should not be disguised as types of evidence for them to be deemed of any value' (Scott-Findlay \& Pollock, 2004, p. 92).

This view may appease the broader medical sector and more closely align the practices of the medical and nursing sectors with the view that evidence is valid when it is objective, quantitative and scientific. However, Scott-Findlay \& Pollock's (2004) suggestion may serve to undervalue evidence from the human perspective and evidence which is derived from intuitive, interpretive and experiential sources may be viewed as less trustworthy when it is termed as findings/knowledge. It could be that when sources of information which are derived from the human perspective are reevaluated as evidence, qualitative approaches can derive validity.

\title{
Evidence-based practice and the library and information sector
}

Evidence-based practice in the library and information sector has been adopted and adapted rather than developed from first principles, possibly because it was in the health sector libraries that evidence-based practice was first used. Definitions of evidence-based practice have been provided by Booth \& Brice (2004); Crumley \& Koufogiannakis (2002); Eldredge (2000). All of these have origins in the field of health librarianship and there are many similarities between these definitions and those that originate from evidence-based medicine. This definition from Crumley \& Koufogiannakis (2002, p. 62) defines evidencebased librarianship as:

A means to improve the profession of librarianship by asking questions as well as finding, critically appraising and incorporating research from library science (and other disciplines)

(C) 2010 IASL, SLAQ and therein by the authors. Diversity Challenge Resilience: School Libraries in Action Proceedings of the $12^{\text {th }}$ Biennial School Library Association of Queensland, the $39^{\text {th }}$ International Association of School Librarianship Annual Conference incorporating the $14^{\text {th }}$ International Forum on Research in School Librarianship, Brisbane QLD Australia, 27 September - 1 October 2010. 
into daily practice. It also involves encouraging librarians to conduct high quality qualitative and quantitative research.

There is recognition in this definition that evidence can come from qualitative and quantitative sources, and a closer look at the models and conceptual frameworks for implementing evidence-based practice for library and information services that have been developed by Booth (2009a), Booth \& Brice (2004), Eldredge (2000), Watson-Boone (2000), and the implementation strategy of Crumley \& Koufogiannakis (2002) indicate a preference for secondary sources of evidence before primary sources. Evidence-based practice in librarianship, like evidence-based medicine, is presented as a process, and the various models have been summarised by Lyons (2009, p.64) as:

Define the problem and identify possible contributing factors

Specify a desired state of affairs

Identify and evaluate alternative solutions for reaching the desired state of affairs

Assess the feasibility and suitability in terms of costs, benefits, and constraints of each alternative solution

Select the most desirable solution and confirm that its specification is complete and understood Prepare a plan to implement the solution, and then implement it

Collect valid data to monitor results, comparing both the implementation and the results to the specification in stet 2 and step 5

If needed, adjust the implementation plan and repeat steps 6 to 8 .

The models of Booth (2009a,b) and Watson-Boone (2000) include a reflective stage that is not specified in the Lyons summary. A similarity in all of these models is that the process favours an action-research approach. Watson-Boone (2000) identifies six additional approaches that could be used in evidence-based practice as:

Action research (a cyclical process of problem identification and resolution involving problem identification, planning, acting, observing, and reflecting) (p.87).

Case study research (a detailed examination of one setting using documents, observations, questionnaires and interviews. It is descriptive and interpretive) (p.88).

Evaluation research (seeks to verify hypotheses; can be summative when it seeks to compare actual performance with previously set performance goals and it is outcomes focused; or formative where data is collected at the program under study is being carried out) (p.86-89).

Experimental research (usually in the form of a pre-test-, post-test on a control group; for instance in bibliographic instruction) (p.89).

Secondary data analysis (the statistics or analysis of data done by another researcher) (p.89).

Survey research (not to be confused with questionnaires which is an instrument to collect data; survey research is a research method; can produce qualitative or quantitative findings) (p.90).

A common feature of medical sector models and these models adapted for the library and information sector is that evidence sources are in a hierarchy and that qualitative sources have a lower ranking than quantitative sources (Booth \& Brice, 2004; Crumley \& Koufogiannakis, 2002; Eldredge, 2000). This preference for secondary sources over primary sources is associated with a concern that when the practitioner becomes the researcher there is potential that the research is not trustworthy and that bias in the investigation may have a bearing on the outcomes of the investigation (Watson-Boone, 2000). However, it has to be recognised that all research, whether quantitative or qualitative is subject to bias, (Hammersley, 2001, 2005; Hargreaves, 1997; Hunsucker, 2007; Lyons, 2009) and to diminish the question of bias, it is necessary to demonstrate that the research is trustworthy.

\section{Evidence-based practice and education}

Evidence-based practice when applied to education attempts to link research, practice and policy, (Furlong \& Oancea, 2005) but in this application, controversy abounds. There are clear divisions between the positivist

(C) 2010 IASL, SLAQ and therein by the authors. Diversity Challenge Resilience: School Libraries in Action Proceedings of the $12^{\text {th }}$ Biennial School Library Association of Queensland, the $39^{\text {th }}$ International Association of School Librarianship Annual Conference incorporating the $14^{\text {th }}$ International Forum on Research in School Librarianship, Brisbane QLD Australia, 27 September - 1 October 2010 . 
perspectives (Chalmers, 2003; Hargreaves, 1997; Oakley, 2001, 2002) and the interpretist perspectives (Elliott, 2001; Hammersley, 2001, 2005, 2008; Oliver \& Conole, 2003). The controversy relates but is not restricted to what constitutes evidence and the nature of research, in particular the reliability or trustworthiness of evidence when the practitioner is the researcher.

Within the interpretist perspective there are questions regarding the trustworthiness of evidence. For instance, using student evaluation as evidence does not legitimize research. The 'what works' strategy, only proves that something can work, and does not explain why it may work (Atkinson, 2000; Oliver \& Conole, 2003). When this approach becomes the focus, evidence-based practice becomes a measure for performance and accountability, and moves to maintain current practice rather than to challenge it (Hammersley, 2005). There is a danger of dressing evidence-based practice up to provide indicator measures of performance and accountability. The 'what works' strategy may validate practice, and provide objective indicators of performance; combine this with results from national testing and there is a danger that a very narrow view of student achievement will be achieved and serves to perpetuate what gets measured gets done (Oliver \& Conole, 2003). These measures serve to maintain rather than transform practice.

The question of trustworthiness of evidence-based practice in education arises when professional judgment and the local context is the basis for decision making. A lack of theory is one criticism leveled at educators when professional judgment is the basis for practice. Yet the everyday practice of education has theoretical underpinnings. Teachers in professional conversation will relate their work to the theories of Bloom and Gardner; their practices to productive pedagogies, higher order thinking, multiple intelligences and authentic assessment. In the educational context what counts as evidence may breach the divide between the positivist and the interpretist approaches.

\section{Evidence-based practice and school libraries}

Oberg (2002) makes a connection between research and the school library sector with an emphasis on evidence gathering that is specific to student achievement. There are basically two ways to gain evidence using the research findings of others (secondary sources) or teacher librarians generating their own research findings (primary sources). Oberg suggests that teacher librarians have reduced opportunities to be involved in original research and should instead rely on the findings of others to and make use of their skills in finding research evidence that supports the work of the teacher librarian (primary based on secondary). This view tends to devalue the professional judgment of the teacher librarian and their expertise in teaching and learning. Oberg does however provide some strategies that would be useful to the teacher librarian to collect local data, to build benchmarks and points of analysis about the local context. Oberg's focus on student achievement could be narrow, as this is not the only area that the teacher librarian can influence, but in a climate of performance standards and national testing it is one that needs consideration.

Lonsdale (2003) recommends action research could be used to raise the profile of teacher librarians; that they take a position of advocacy and use evidence-based practice to demonstrate their contributions to student achievement. Todd also has long been an advocate of the teacher librarian and in his 'Manifesto' calls for evidence-based practice to be applied to teacher librarianship (2008). For various reasons school libraries in Australia are struggling for survival (Booth, 2009b; Brooks, 2007; Kenney, 2006; Todd, 2007, 2008) and evidence-based practice may be a way forward for teacher librarians (Amoore \& Gillespie, 2009). Lyons (2009) however is critical of using evidence-based practice for advocacy. 'Advocacy has no place in EBP and EBM' (Lyons, 2009, p.65). Evidence-based practice according to Lyons should be client centred, and to use evidence-based practice for advocacy takes away the rigour and impartiality that is required to make informed decisions from the evidence presented. Lyons is critical of action research where the practitioner is the researcher and whether this approach should play a part in evidence-based practice. Perhaps the view of Lyons (2009) is more closely aligned with the scientific and structured view of evidence and therefore disregards advocacy supported by trustworthy evidence which is derived from a local context.

(C) 2010 IASL, SLAQ and therein by the authors. Diversity Challenge Resilience: School Libraries in Action Proceedings of the $12^{\text {th }}$ Biennial School Library Association of Queensland, the $39^{\text {th }}$ International Association of School Librarianship Annual Conference incorporating the $14^{\text {th }}$ International Forum on Research in School Librarianship, Brisbane QLD Australia, 27 September - 1 October 2010. 
As a guide for developing evidence-based practice Todd (2008) recommends that teacher librarians take a holistic approach and to be systematic in the collection of evidence that shows how their practices impact on student learning. The holistic approach involves three dimensions:

Evidence for practice (uses empirical research to inform best practice)

Evidence in practice (integrating research, professional experience and local evidence to bring about optiminal learning outcomes)

Evidence of practice (systematic, measured student data)

(Todd, 2008, p. 40)

This model places evidence into three categories where the three aspects of evidence-based practice do not seem to be linked and are not sequential. There does not seem to be theory development or research to support this model. Evidence FOR practice and Todd's use of the term empirical research indicates that to inform best practice there is a need to consult the formal research and follows the approach of the medical models. Making a distinction of evidence IN practice and evidence OF practice draws this model of evidence-based practice closer to the needs of teacher librarians, but how the next two stages on the model are utilised or implemented by practitioners is less clear. This lack of clarity could lead to misinterpretation with a need for further clarification, unpacking and links to practice.

Gordon's continuing (2009a,b) research relates to information literacy and student learning and places action research as a viable approach for evidence-based practice. This research is more than action research, as the action research method supports a "user-centric view of information seeking, a constructivist view of learning, and a process approach to library and information services that grows from the ISP (Information Search Process) and Guided Inquiry (Gordon, 2009a, p.63). The emerging theory from Gordon's research (2009b) 'posits that evidence-based information literacy instruction uses action research as a tool of evidence-based practice' (p.38). This research has a focus on information literacy and the pedagogy of Guided Inquiry. While this research may serve to inform evidence-based practice for teacher librarians, it has a reliance on the Guided Inquiry approach and it may not tell the whole story of their involvement in student achievement and social and cultural development.

While Lyons (2009) believes that evidence-based practice should not easily abandon its core tenants of client focus and rigour, Booth (2009b) suggests we should be more lenient with our definitions of evidence and expand methods of data collection. The complexity and dual nature of teacher librarianship may mean that teacher librarians will not adopt or adapt evidence-based practice as it has been presented in the medical, education or library and information sectors, but instead create something that is unique to their profession.

\section{A short history of teacher librarianship and the role of the teacher librarian in Australia}

Qualified teacher librarians in Australia have dual qualifications. After attaining a degree in education they then undertake a Masters level qualification in teacher librarianship or librarianship. Teacher librarianship studies include learning pedagogy, information literacy, library management, collection development and the use of information technologies in learning. In most Australian schools the teacher librarian operates with the support staff of library technicians and/or library aides. In some larger schools which cater for all the years of schooling, and multi campus schools, there may be more than one qualified teacher librarian. In the school environment the focus is on students, teachers, classrooms and learning. The support role that the teacher librarian plays makes it difficult to gain recognition for the role that they play in student learning. With their impact in student learning largely unrecognized the flow on effect is that it is very easy for the teacher librarian and the library itself to be undervalued and overlooked (Hartzell, 1997a,b).

The Australian Library and Information Association (ALIA) and Australian School Library Association (ASLA) are the two professional bodies which accredit teacher-librarianship training and provide professional guidance. The joint Statement on teacher librarians in Australia from ALIA and ASLA (2003, Rev. 2009) states:

(C) 2010 IASL, SLAQ and therein by the authors. Diversity Challenge Resilience: School Libraries in Action Proceedings of the $12^{\text {th }}$ Biennial School Library Association of Queensland, the $39^{\text {th }}$ International Association of School Librarianship Annual Conference incorporating the $14^{\text {th }}$ International Forum on Research in School Librarianship, Brisbane QLD Australia, 27 September - 1 October 2010. 
Principle

Teacher librarians support and implement the vision of their school communities through advocating and building effective library and information services and programs that contribute to the development of lifelong learners.

\title{
Statement
}

The teacher librarian is a leader within the educational community. The valuable role of the teacher librarian focuses on:

\author{
Learners and learning; \\ Teachers and teaching; \\ Resourcing the curriculum; \\ Facilitating access to information; \\ Developing the physical environment.
}

The statements, learners and learning and teachers and teaching and resourcing the curriculum are the three elements which make a point of delineation between teacher-librarians and library and information professionals in other sectors.

School libraries are a place of changing focus, attempting to respond to the changing information and recreational needs of their school community. Despite the teacher librarians' potential to contribute to student learning, there is limited awareness and recognition of the role. As a result, teacher librarians often lament that the services offered through their school libraries are undervalued (Hartzell, 2002, 2003). 'While many teacher librarians are keen to integrate technology and popular culture into the learning experience, they do not always have the skills or support to do so. Furthermore, there is strong evidence to suggest that the library, as an essential but sometimes undervalued space within the school is literally shrinking' (Brooks, 2007, p.21). Teacher librarians need to demonstrate their value, "no-one is going to rescue school librarians [and the fact that they are undervalued] but themselves' (Kenney, 2006, p.45).

This research responds to the need, by building on a previous exploratory study that I conducted (Gillespie, 2007) to gain understandings of the challenges that teacher librarians encounter and the contributions that they can make to student literacy standards. The findings of the exploratory study (Gillespie, 2007) indicated that all of the teacher librarians were committed to good practice and had these characteristics and attitudes in common:

- A strong conviction from each teacher librarian that they had a positive impact on the literacy levels of the students;

- The work they did with the classes in a teaching role always took priority;

- The provision of information and resource delivery for teachers was a high priority;

- Making the library accessible by providing opening times outside of school hours and making the library an inviting space was also important (p.55).

This exploratory study concluded that there was a strong statistical correlation between the schools that attained the highest national test scores for literacy and the role that the school library and the teacher librarian took in the school in regard to teaching and learning. These findings correspond to the findings of the large scale studies conducted in the Ohio School Libraries by Todd and Kuhlthau (2005a,b).

Loertscher (2009) considers that the teacher librarian cannot afford to wait for a comfortable and predictable evolutionary model of evidence based practice. A revolutionary approach is suggested, which involves reflective practice where the question 'What difference has it made?' is asked over and over again (p.181). The exploration so far seems to indicate that evidence derived from local sources could be highly valued and could provide the most reliable information to guide future direction and planning for the library. For the teacher librarian, using evidence to demonstrate contributions to student achievement is a verification of the

(C) 2010 IASL, SLAQ and therein by the authors. Diversity Challenge Resilience: School Libraries in Action Proceedings of the $12^{\text {th }}$ Biennial School Library Association of Queensland, the $39^{\text {th }}$ International Association of School Librarianship Annual Conference incorporating the $14^{\text {th }}$ International Forum on Research in School Librarianship, Brisbane QLD Australia, 27 September - 1 October 2010. 
value to teaching and learning. From the literature that has been explored the research questions - What constitutes evidence-based practice in teacher librarianship? and Within the context of teacher librarianship and evidence based practice - what is evidence? remains unresolved and indicates that a framework for evidence based practice for teacher librarians is necessary.

\section{Method}

This research is still ongoing and at this stage a preliminary pilot study has been conducted. The findings described here are drawn from the preliminary pilot study; while the sample, questions and method describe the intent for the whole research. Inadequacies in the approach have been identified from the initial pilot study and changes to the method are explained.

\section{Aims and objectives of the research}

This research has one central objective and two aims which are the focus questions of this research. The central objective is:

How teacher librarians perceive and use evidence based practice to demonstrate their contributions to the social, cultural and academic achievements of their students.

The research questions are the more specific aims of the research. The two questions are:

What constitutes evidence-based practice in teacher librarianship?

and

Within the context of evidence-based practice and teacher librarianship - what is evidence?

The research contribution will be:

To devise a framework of evidence-based practice for teacher librarians which as been developed from a foundation in research.

\section{The research approach}

This research takes a qualitative, interpretist approach. Such an approach is favoured in the social sciences, coupled with my own background as a teacher librarian it makes a fit between the method and the research questions (Williamson, Burstein \& McKemmish, 2002). There is a risk that not providing structure to the interviews and observations could result in the research questions not being answered. The in-depth investigations will utilise three data collection instruments - semi-structured interviews; the Henri, Hay \& Oberg Rubric for an Information Literate School (2002, p. 89); and Information Horizon (Sonnenwald , 2005). It is proposed that Expanded Critical Incident Technique (ECIA) developed by Hughes (2007) could provide a structure to maintain the focus of the evidence gathering and analysis.

\section{Initial pilot study}

The initial pilot study utilised The Critical Incident Technique (CIT) designed by John Flanagan who describes it as:

A set of procedures for collecting direct observations of human behaviour in such a way as to facilitate their potential usefulness in solving practical problems and developing board psychological principles. The critical incident technique outlines procedures for collecting observed incidents having special significance and meeting systematically defined criteria (Flanagan, 1954, p. 327).

CIT is a qualitative, structured, positivist approach which allows the researcher to capture the actions of the participants. The analysis takes a structured binary approach. Flanagan outlined a five step sequential process of implementation:

(C) 2010 IASL, SLAQ and therein by the authors. Diversity Challenge Resilience: School Libraries in Action Proceedings of the $12^{\text {th }}$ Biennial School Library Association of Queensland, the $39^{\text {th }}$ International Association of School Librarianship Annual Conference incorporating the $14^{\text {th }}$ International Forum on Research in School Librarianship, Brisbane QLD Australia, 27 September - 1 October 2010. 
Establish the general aims

Establish the plans and specifications

Collect the data

Analyse the data

Interpret and report on the data

CIT focuses on real life incidents of a critical nature - that is the incident could have caused a change, an insight, a revelation that was previously not evident. CIT is useful for exploratory research which attempts to answer What questions; as in the case of this research What constitutes evidence based practice in teacher librarianship?

Initial analysis from the preliminary pilot study disclosed some common themes; however inconsistent results regarding the context or environment of the participants were problematic. The literature has revealed that the school library and the work of the teacher librarian cannot be investigated in isolation because the school library is part of an organisation. Some of this information was revealed in the interviews, but it was of an incidental nature, making comparison from one data set to another impossible. At the conclusion of the initial pilot it became clear to me that modifications were needed to the approach. CIT has been seen as adaptable and modifiable and perhaps it could be modified to better fit this research.

\section{Changes to the approach}

CIT is a flexible strategy where the principles can be 'modified and adapted to meet the specific situation at hand' (Flanagan, 1954, p.335). Later uses of CIT have been in the social sciences, used by Kain (1997) in education and Radford (2006) from information sciences, both having close alignment to this research.

The CIT in its expanded form (ECIA) as described by Hughes (2007) includes 'the identification of critical incidents and the recording of critical behaviours' (p.53). Hughes modified (expanded) and applied CIT to include seeking 'insight through their actions, thoughts and feelings' (Hughes, 2007, p.51) when investigating how international students use online information resources to learn. These three studies from the education and library sciences informed the approach for this research.

Using ECIA, the analysis is inductive and interpretive. Taking a more interpretist approach would allow the exploration of the complexities and inter-relationships of people and events; that is the way they perceive their worlds (Green, 2006). To capture the rich sources of information in her own study, Hughes (2007) made two basic changes to CIT. The semi-structured interviews took a more holistic focus to allow actions, thoughts, feeling and influences of the participants to be captured. This took CIT beyond purely behavioural aspects to answer how and why aspects. Secondly observations of the participants in a set task were able to answer how well they performed. This dual approach allowed Hughes to draw on personal accounts as well as her own objective assessment of their effectiveness, thus enhancing the trustworthiness of the data. The ECIA was able to provide much rich, in-depth data with the dual approach.

\section{Description of sample}

Purposeful sampling will be applied, and the participants will be selected because of their relevance to the research questions (Silverman, 2000). This research is about teacher librarians, and following the ALIA/ASLA Statement on teacher librarians in Australia (2003, Rev. 2009), I am seeking to include qualified teacher librarians currently working in Australian schools. The sample of participants for the research will be representative of teacher librarians from as many states in Australia and from as many sectors and school configurations (single campus, multi campus and school size) as possible.

\section{Description of instruments}

The data collection instruments will enable teacher librarians to tell their story through a variety of modes. The instruments include face to face interviews, involving open ended questions; the Henri, Hay \& Oberg Rubric for an Information Literate School (2002, p. 89) to provide additional context of the school

(C) 2010 IASL, SLAQ and therein by the authors. Diversity Challenge Resilience: School Libraries in Action Proceedings of the $12^{\text {th }}$ Biennial School Library Association of Queensland, the $39^{\text {th }}$ International Association of School Librarianship Annual Conference incorporating the $14^{\text {th }}$ International Forum on Research in School Librarianship, Brisbane QLD Australia, 27 September - 1 October 2010. 
environment; and the Sonnenwald (2005) Information Horizon to provide the interview participants with an alternative descriptor for their evidence gathering approach.

The preliminary pilot investigation revealed some inadequacies in the interview questions. These questions have now been reworked to provide the opportunity for the whole story to be told. The revised interview questions relate to:

\section{School demographic and context questions}

School populations, secondary, primary, mixed, sector and general location.

Tell me about your role in the school.

Tell me about your impact on teaching and learning

How do the things you do impact on teaching and learning?

Tell me about your impact on library management.

How do the things you do impact on the management of the library?

How do you evaluate your role?

Questions relating to evidence approaches

\begin{tabular}{|l|}
\hline $\begin{array}{l}\text { Can you describe an evidence gathering approach you have } \\
\text { adopted? }\end{array}$ \\
\hline How did you do this? \\
\hline Why did you do this? \\
\hline $\begin{array}{l}\text { Would you consider this to be a successful evidence gathering } \\
\text { approach? }\end{array}$ \\
\hline Why? \\
\hline $\begin{array}{l}\text { What would you consider to be the principal outcome of the } \\
\text { evidence gathering you undertook? }\end{array}$ \\
\hline What would you consider to be advantages of this approach? \\
\hline What would you consider to be the disadvantages of this approach? \\
\hline $\begin{array}{l}\text { Can you describe any strategies you have tried that were not } \\
\text { effective measures of evidence? }\end{array}$ \\
\hline $\begin{array}{l}\text { Why do you think this strategy was not successful or an ineffective } \\
\text { measure of evidence? }\end{array}$ \\
\hline
\end{tabular}

Additionally information will be gained from:

Information Horizon. Draw a picture or diagram of all of your information sources

Can you describe this drawing? (Identify the information sources and label them if necessary)

and

Rubric for an information literate school. Use a highlighter to indicate where your school is situated on the rubric.

These two additional instruments are to provide insights which go beyond the interview questions, and have the potential to reveal more about the role that the teacher librarian performs in each school setting.

\section{Limitations}

This is a real world research and there will be limitations and restrictions which will impact upon what can be achieved. Limitations have been identified as:

(C) 2010 IASL, SLAQ and therein by the authors. Diversity Challenge Resilience: School Libraries in Action Proceedings of the $12^{\text {th }}$ Biennial School Library Association of Queensland, the $39^{\text {th }}$ International Association of School Librarianship Annual Conference incorporating the $14^{\text {th }}$ International Forum on Research in School Librarianship, Brisbane QLD Australia, 27 September - 1 October 2010 . 
Accessibility to schools;

Time and distance;

Reliability of interview information

One limitation is in complying with ethics requirements in gaining information from schools, especially in the government and Catholic sectors. The constraints around accessibility to schools will be adhered to and the guidelines followed. A whole of Australia focus may not be achievable by one researcher, and making use of places where teacher librarians gather is one solution; another is to travel to a central locations and conduct interviews in a group of schools within a close proximity. In regard to reliability, in utilising semistructured interviews there will be questions regarding how much of what is said is a true picture.

\section{Reliability}

To be a reliable and trustworthy research investigation, this research needs to represent the true perceptions of teacher librarians and evidence-based practice. All attempts will be made to ensure that the true voice of the teacher librarian is heard (Silverman, 2000). Interviews will be recorded and transcribed by the researcher and verified by the participant. Ethical standards will be applied and no participants or their locations will be identified. Actual transcripts (unidentified) and vignettes will be included in the discussion to provide real examples of the themes that emerge from the data analysis. In using the voices of the interviewees, the links to data and analysis will be transparent.

\section{Findings from preliminary pilot study}

The purpose of the preliminary pilot study was to test the interview questions, data gathering instruments and devising a strategy to manage the data analysis. Three teacher librarians from different states and school sectors (government, independent and Catholic) took part in the preliminary interviews at the ASLA conference in Perth, October, 2009. The preliminary insights (summarized below) are promising; however they cannot be used as predictors for the final outcome of the research.

\section{All three teacher librarians indicated that:}

They had built good relationships with their principal, staff and students.

They were addressing user needs in their actions for change

They held strong convictions that their work was for the benefit of the students and teachers at their schools Their actions and interventions would impact on the whole school, not just the library

They had attitudes that were proactive, supportive, and positive and were able to negotiate

They were all providing timetabled relief time for class teachers and therefore were not working as collaborative teaching partners

They were relying on primary based on secondary sources of evidence; that is they were using local data generated from their own work practices or library database

They were reflective of their actions constantly striving to do things better

They were most successful when the school principal actively supported the interventions

They were well skilled in the use of ICTs and the applications to learning

They were leaders of professional development

They were leaders of learning innovations and users of ICTs in learning

The culture of the school governed how they worked with students and teachers

\section{Some of the teacher librarians indicated that:}

They were collaboratively planning though not always on a regular basis with class teachers

Through their teaching interactions they were working to build strong links between the learning in the

library and the learning in the classroom

Lack of access to staff was a barrier to successful interventions

They had an awareness of pedagogies for student learning

They were adapting teaching and learning strategies to suit the culture of their school

(C) 2010 IASL, SLAQ and therein by the authors. Diversity Challenge Resilience: School Libraries in Action Proceedings of the $12^{\text {th }}$ Biennial School Library Association of Queensland, the $39^{\text {th }}$ International Association of School Librarianship Annual Conference incorporating the $14^{\text {th }}$ International Forum on Research in School Librarianship, Brisbane QLD Australia, 27 September - 1 October 2010. 
None of the teacher librarians indicated:

A use of primary sources, or original research where they conducted their own research as the foundation of evidence building

\section{Next steps}

The preliminary pilot study indicated that the context (workplace or work situation) did play a part in the role the teacher librarian was able to perform in the school. The changes made to the data collection and analysis provide opportunity to expose the wider extent of influence of the teacher librarian. These changes will be tested in a second pilot study before advancing to the final stages of interviews and data analysis.

\section{Conclusion}

It is proposed in this study that evidence-based practice has the potential to demonstrate the influence the teacher librarian has on student social, cultural and academic achievement. This paper has introduced current research which addresses the need for a framework for evidence-based practice which applies to teacher librarians. It will also contribute understanding about What is evidence, a complex question which has not yet been conclusively answered by other researchers. In particular, the research will respond to a significant observation arising from the preliminary interviews and a dilemma for this researcher regarding What $a$ teacher librarian considers to be evidence.

\section{References}

Amoore, S. \& Gillespie, A. (2009). The early implications of the national curriculum: The way ahead for teacher librarians. Access, 23(3), 16 - 18.

Atkinson, E. (2000). In defence of ideas, or why 'What Works' is not enough. British Journal of Sociology of Education 21(3), 317 - 330. Retrieved 22 April, 2010, from JSTOR database.

Australian Library and Information Association (ALIA) \& Australian School Library Association (ASLA). (2003. Rev. 2009). Statement on teacher librarians in Australia. Retrieved 8 May, 2009, from http://www.asla.org.au/policy/teacher.librarians.Australia.htm.

Booth, A. (2009a). EBLIP five-point zero: towards a collaborative model of evidence-based practice. Health Information and Libraries Journal 26(4), 341 - 344. Retrieved 28 December, 2009, from Wiley InterScience database.

Booth, A. (2009b). A bridge too far? Stepping stones for evidence based practice in an academic context. New Review of Academic Librarianship 15(3), 3 - 34. Retrieved 8 January, 2010, from State Library of NSW document delivery.(Document ID: 10.1080/13614530903123534).

Booth, A. \& Brice, A. (2004). Why evidence-based information practice? In A. Booth \& A. Brice (Eds.), Evidence-based practice for information professionals: A handbook (p. 1-12). London: Facet.

Brooks, K. (2007). Honey, I shrunk the library: Technology, cyberspace and knowledge culture. Access, 21(1), $21-26$.

Chalmers, I. (2003). Trying to do more good than harm in policy and practice: the role of rigorous, transparent, up-to-date evaluations. Annals of the American Academy of Political and Social Science 589, 22 - 40. Retrieved 26 April, 2010, from Sage Online database. (Document ID: 10.1177/0002716203254762).

Crumley, E. \& Koufogiannakis, D. (2002). Developing evidence-based librarianship: Practical steps for implementation. Health Information \& Libraries Journal 19(2), 61 - 70. Retrieved 5 May, 2009, from Academic Search Elite database.

(C) 2010 IASL, SLAQ and therein by the authors. Diversity Challenge Resilience: School Libraries in Action Proceedings of the $12^{\text {th }}$ Biennial School Library Association of Queensland, the $39^{\text {th }}$ International Association of School Librarianship Annual Conference incorporating the $14^{\text {th }}$ International Forum on Research in School Librarianship, Brisbane QLD Australia, 27 September - 1 October 2010. 
Eldredge, J. D. (2000). Evidence-based librarianship: An overview. Bulletin of the Medical Library Assoc 88(4), 289 - 302. Retrieved 14 April, 2009, from Academic Search Elite database.

Elliott, J. (2001). Making evidence-based practice educational. British Educational Research Journal 27(5), 555 - 574. Retrieved 3 May, 2010, from Academic Search Elite database. (Document ID: 10.1080/0141192120095735).

Flanagan, J. C. (1954). The critical incident technique. The Psychological Bulletin 51(4), 327 - 358. Retrieved from http://www.analytictech.com/mb870/Readings/flanagan.pdf.

Furlong, J. \& Oancea, A. (2005). Assessing quality in applied and practice-based educational research: a framework for discussion. Oxford Department of Educational Studies, Retrieved 3 May, 2010, from http://www.bera.ac.uk/pdfs/Qualitycriteria.pdf.

Gillespie, A. (2007). Teacher librarian contributions to student literacy standards. Faculty of Information Technology. Brisbane, Queensland University of Technology: 85.

Gordon, C. (2009a). An emerging theory for evidence based information literacy instruction in school libraries, Part 1. Evidence Based Library and Information Practice 4(2), 56 - 77. Retrieved 27 December, 2009, from http://ejournals.library.ualberta.ca/index.php/EBLIP/article/view/5614/5320

Gordon, C. (2009b). An emerging theory for evidence based information literacy instruction in school libraries, Part 2. Evidence Based Library and Information Practice 4(3), Retrieved 27 December, 2009, from http://ejournals.library.ualberta.ca/index/php/EBLIP/article/view/6449/5559

Grahame-Smith, D. (1995). Evidence based medicine: Socratic dissent. BMJ 310(April), 1126 - 1127. Retrieved 21 December, 2009, from BMJ database.

Green, M. L. (2006). Evaluating evidence-based practice performance. Evidence Based Medicine 11(August), 99 - 101. Retrieved 2 January, 2010, from BMJ database.

Hammersley, M. (2001). Some questions about evidence-based practice in education. In R. Pring\&G. Thomas (Eds.), Evidence-based Practice in Education (pp.133 - 149). Maidenhead, Berkshire: Open University Press.

Hammersley, M. (2005). Is the evidence-based practice movement doing more good than harm? Reflections on Iain Chalmers' case for research-based policy making and practice. Evidence \& Policy 1(1), 85 - 100. Retrieved 26 April, 2010, from Ingenta Connect.(Document ID: 10.1332/1744264052703203).

Hammersley, M. (2008). Troubling criteria: a critical commentary on Furlong and Oancea's framework for assessing educational research. British Educational Research Journal 34(6), 747 - 762. Retrieved 8 March, 2010, from Academic Search Elite database. (Document ID: 10.1080/01411920802041590).

Hargreaves, D. H. (1997). In defence of research for evidence-based teaching. British Educational Research Journal 23(4), Retrieved 26 April, 2010, from Academic Search Elite database.

Hartzell, G. N. (1997a). The invisible school librarian: Why other educators are blind to your value (part 1). School Library Journal 11(1), Retrieved 20 October, 2006, from Academic Search Elite database

Hartzell, G. N. (1997b). The invisible school librarian: Why other educators are blind to your value (part 2). School Library Journal 11(1), Retrieved 20 October, 2006, from Academic Search Elite database

Hartzell, G. N.(2002). Why should school principals support school libraries? ERIC Digest, 2002 (11), Retrieved 5 January, 2010, from Academic Search Elite Database.

(C) 2010 IASL, SLAQ and therein by the authors. Diversity Challenge Resilience: School Libraries in Action Proceedings of the $12^{\text {th }}$ Biennial School Library Association of Queensland, the $39^{\text {th }}$ International Association of School Librarianship Annual Conference incorporating the $14^{\text {th }}$ International Forum on Research in School Librarianship, Brisbane QLD Australia, 27 September - 1 October 2010. 
Hartzell, G. N. (2003). Building influence for the school librarian: tenents, targets \& tactics. Worthington, Ohio: Linworth Publishing

Henri, J., Hay, L. \& Oberg, D. (2002). The school library-principal relationship. The Hague: International Federation of Library Associations and Institutions (IFLA).

Hughes, H. (2007). Critical incident technique. In S. Lipu, K. Williamson \& A. Lloyd (Eds.), Exploring methods in information literacy research (pp.49 - 66). Wagga Wagga, NSW: Centre for Information Studies.

Hunsucker, R. L. (2007). The theory and practice of evidence-based information work - one world? In EBLIP4: 4th International Evidence Based Library and Information Practice Conference Chapel Hill, Durham, NC.

Kain, D. L. (1997). Critical incidents in teacher collaboration on interdisciplinary teams. Research in Middle Level Education Quarterly, 21(1), 1 - 9.

Kenney, B. (2006). Ross to the rescue. School Library Journal 52(4), 44 - 47. Retrieved 5 January, 2010, from Academic Search Elite database.

Kitson, A., Harvey, G. \& McCormack, B. (1998). Enabling the implementation of evidence based practice: a conceptual framework. Quality Health Care 7, 149 - 158. Retrieved 14 December, 2009, from BMJ database.

Loertscher, D. V. (2009). Evidence-based practice: evolution or revolution? Evidence Based Library and Information Practice (EBLIP) 4(2), 178 - 181. Retrieved 27 December, 2009, from http://ejournals.library.ualberta.ca/index.php/EBLIP/article/view/6140/5336.(Document ID: 6140/5336).

Little, M. (2003). Better than numbers....A gentle critique of evidence-based medicine. ANZ Journal of Surgery Apr 2003 73(4), 177 - 182. Retrieved 14 December, 2009, from Academic Search Elite.

Lomas, J. (1993). Retailing research: increasing the role of evidence in clinical services for childbirth. The Milbank Quarterly 71(3), 439 - 475. Retrieved 23 December, 2009, from JSTOR database.

Lonsdale, M. (2003). Impact of school libraries on student achievement: a review of the research. Report for the Australian School Library Association: Australian Council for Educational Research.

Lyons, R. (2009). The call for evidence based practice: speaking louder than words. Evidence Based Library and Information Practice 4(3), 63 - 67. Retrieved 21 April, 2010, from

http://ejournals.library.ualberta.ca/index.php/EBLIP/issue/view/458.

Oakley, A. (2001). Making evidence-based practice educations: a rejoiner to John Elliott. British Research Journal 27(5), 575 - 576. Retrieved 3 May, 2010, from Academic Search Elite database.(Document ID: $10.1080 / 01411920120095744)$.

Oakley, A. (2002). Social science and evidence-based everything: the case of education. Educational Review 54(3), 277 - 286. Retrieved 21 April, 2010, from Academic Search Elite.(Document ID:

10.1080/0013191022000016329).

Oberg, D. (2002). Looking for evidence: do school libraries improve student achievement? School Libraries in Canada 22(2), 10 - 13. Retrieved 29 December, 2009, from Academic Research library.

(C) 2010 IASL, SLAQ and therein by the authors. Diversity Challenge Resilience: School Libraries in Action Proceedings of the $12^{\text {th }}$ Biennial School Library Association of Queensland, the $39^{\text {th }}$ International Association of School Librarianship Annual Conference incorporating the $14^{\text {th }}$ International Forum on Research in School Librarianship, Brisbane QLD Australia, 27 September - 1 October 2010. 
Oliver, M. \& Conole, G. (2003). Evidence-based practice and e-learning in higher education: can we and should we? Research Papers in Education 18(4), 385 - 397. Retrieved from Academic Search Elite database.(Document ID: 10.1080/0267152032000176873).

Radford, M. L. (2006). The critical incident technique and the qualitative evaluation of the connecting libraries and schools project. Library Trends 55(1), 46 - 65. Retrieved 20 May, 2009, from ProQuest database.

Rosenberg, W. \& Donald, A. (1995). Evidence based medicine: an approach to clinical problem-solving. BMJ 310(April), 1122 - 1126. Retrieved 21 December, 2009, from BMJ database.

Rycroft-Malone, J., Seers, K., Titchen, A., Harvey, G., Kitson, A. \& McCormack, B. (2004). What counts as evidence in evidence-based practice? Journal of Advanced Nursing 47(1), 81 - 90. Retrieved 14 December, 2009, from CINAHL database.

Sackett, D., Rosenberg, W., G. Muir Gray, J. A., Haynes, R. B. \& Richardson, W. (1996). Evidence based medicine: What it is and what it isn't. BMJ 312(January), 71 - 72. Retrieved 14 December, 2009, from BMJ database.

Scott-Findlay, S. \& Pollock, C. (2004). Evidence, research, knowledge: a call for conceptual clarity. Worldviews on Evidence-Based Nursing 2nd Quarter 1(2), 98 - 101. Retrieved 14 December, 2009, from CINAHL database.

Silverman, D. (2000). Doing qualitative research. London: Sage Publications.

Sonnenwald, D. H. (2005). Information Horizons. In K. E. Fisher, S. Erdelez \& L. E. F. McKechnie (Eds.), Theories of information behaviour (pp.191 - 197). Medford, New Jersey: Information Today, Inc.

Todd, R. J. (2008). The evidence-based manifesto. School Library Journal 54(4 April), 38 - 43. Retrieved 10 March, 2009, from Academic Search Elite database.

Todd, R. J. (2007). Evidence-based practice and school libraries: From advocacy to action. In S. HughesHassell\&V. H. Harada (Eds.), School reform and the school library media specialist (pp.57 - 78). Westport, CT: Libraries Unlimited.

Todd, R. J. \& Kuhlthau, C. (2005a). Student learning through Ohio school libraries, Part 1: How effective school libraries help students. School Libraries Worldwide, 11(1), 63 - 88.

Todd, R. J. \& Kuhlthau, C. (2005b). Student learning through school libraries, Part2: Faculty perceptions of effective school libraries School Libraries Worldwide, 11(1), 89 - 110.

Watson-Boone, R. (2000). Academic librarians as practitioner-researchers. Journal of Academic Librarianship 26(2), 85 - 93. Retrieved 30 December, 2009, from Academic Search Elite database.

Williamson, K., Burstein, F. \& McKemmish, S. (2002). The two major traditions of research. In K. Williamson (Eds.), Research methods for students, academics and professionals : Information management and systems (pp.25 - 48). Wagga Wagga, NSW: Centre for Information Studies.

\section{Statement of Originality}

This statement certifies that the paper is based upon original research undertaken by the author and that the paper was conceived and written by the author alone and has not been published elsewhere. All information and ideas from others is referenced.

(C) 2010 IASL, SLAQ and therein by the authors. Diversity Challenge Resilience: School Libraries in Action Proceedings of the $12^{\text {th }}$ Biennial School Library Association of Queensland, the $39^{\text {th }}$ International Association of School Librarianship Annual Conference incorporating the $14^{\text {th }}$ International Forum on Research in School Librarianship, Brisbane QLD Australia, 27 September - 1 October 2010. 